\section{The effect of prosthetic margin location on caries susceptibility. A systematic review and meta-analysis}

\author{
S. N. Papageorgiou, ${ }^{1}$ A. P. Papadelli, ${ }^{2}$ P. T. Koidis ${ }^{3}$ and H. P. Petridis ${ }^{* 4}$
}

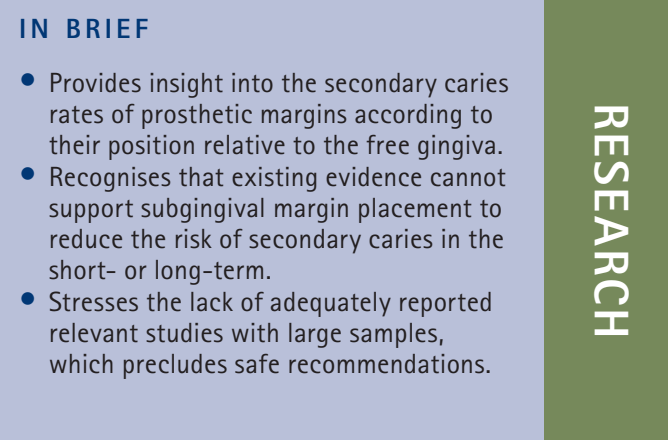

\begin{abstract}
Background The prosthetic margin location relevant to the free gingival margin may influence the incidence of secondary caries due to the differences that exist between the micro-environment within the gingival crevice compared to the rest of the oral environment. Objective The purpose of this study was to systematically review the effect of prosthetic margin placement on caries susceptibility of abutment teeth. Method Two independent authors identified cohort studies using MEDLINE, EMBASE, CDSR, CENTRAL, Google Scholar and Scopus through March 2012. Reference lists were also scanned. Included studies had to report on caries incidence with regard to location of prosthetic margins, with a minimum followup period of two years. Results A total of 5,541 references were identified and, after application of the inclusion criteria, 22 studies were included in the systematic review. Random-effects meta-analysis could be made in two studies, in which secondary caries incidence did not differ between margins placed subgingivally compared to equi- or supragingivally placed margins for a follow-up period up to ten years. Indications were found of a possible lower secondary caries rate at 15 years of follow up, based on one study. Conclusion This systematic review and meta-analysis failed to detect a significantly different secondary caries rate of subgingivally located prosthetic margins in the short to mid-term ( $\leq 10$ years). Due to the small number and the limitations of the included studies the results do not provide conclusive evidence as to the effect of prosthetic margin placement on the incidence of secondary caries.
\end{abstract}

\section{INTRODUCTION}

Dental caries is a progressive disease existing as a result of bacterial biological processes that affect dental tissues (enamel, dentine and cementum) and is dietary-dependent and host-specific. ${ }^{1}$ If left untreated, it results in the formation of lesions on the tooth's surface (initially as chalky white spots), whose final stage is the development of cavities. Two bacteria species are mainly responsible for dental decay, Streptococcus mutans ${ }^{2}$ (SM) and Lactobacillus ${ }^{3}$ (LB), both found in the normal oral microbiota. Although the bacterial community in dental plaque is

'Doctoral Candidate, Department of Oral Technology, School of Dentistry, University of Bonn, Bonn, Germany; ${ }^{2}$ Dentist, School of Dentistry, Aristotle University of Thessaloniki, Thessaloniki, Greece; ${ }^{3}$ Professor and Head, Department of Fixed Prosthodontics and Implant Prosthesis, School of Dentistry, Aristotle University of Thessaloniki, Thessaloniki, Greece; ${ }_{4}^{4}$ Senior Lecturer, Department of Restorative Dentistry, Prosthodontics Unit, UCL Eastman Dental Institute, London, UK ${ }^{*}$ Correspondence to: Dr Haralampos P. Petridis Email: c.petridis@ucl.ac.uk; Tel: 02034561250

\section{Refereed Paper}

Accepted 12 March 2013

DOI: 10.1038/sj.bdj.2013.582

${ }^{\circledR}$ British Dental Journal 2013; 214: 617-624 complex, evidence suggests that SM is associated with caries initiation, while Lactobacillus is associated with caries progression. ${ }^{4-6}$ Caries is one of the most common reasons for tooth loss worldwide, while caries susceptibility depends upon age, diet, region, social status, race and many other parameters. ${ }^{7-13}$ Caries and/or loss of retention have been reported to be the primary cause of failures of fixed prostheses. ${ }^{14}$ Early and more extended adherence of SM on restoration margins has been found in patients presenting with high caries susceptibility. ${ }^{15}$ Prosthetic restoration margins present with an increased risk compared to natural tooth surfaces for caries occurrence, even when the prostheses have an acceptable fit. ${ }^{16}$

The tooth offers different sites for bacterial colonisation both above the gingival margin (supragingival) and below it (subgingival). The microflora of the healthy gingival crevice tends to consist of relatively few cells and is predominated by Gram-positive organisms, mainly Streptococcus species and Actinomyces species. Many of these strains are thought to be commensals, and a smaller number, opportunistic pathogens. ${ }^{17}$ Spirochaetes appear sporadically increased in 7- and 14-day-old subgingival plaque. Grampositive rods are predominant in developing supragingival plaque, whereas motile rods and spirochaetes are found in slightly higher proportions in ageing subgingival plaque. Apart from these minor differences, the composition of supragingival and subgingival plaque during a two week period of plaque development was similar. ${ }^{18,19}$ However, the micro-environment within the gingival crevice has some differences compared to the rest of the oral environment. The principal source of nutrients is not saliva but the gingival crevicular fluid, which is similar to plasma, from which it originates, in that it contains protein, albumin, leucocytes, immunoglobulins and complement. ${ }^{5}$ The subgingival conditions are anaerobic and the gingival crevice is not exposed to dietary components and the buffering role of saliva. The alkaline $\mathrm{pH}$ of the gingival crevices/periodontal pockets may selectively induce the colonisation by periodontopathogens. ${ }^{5,20,21}$ These potential 
environmental differences may have an effect on caries susceptibility of abutment teeth with subgingival prosthetic margins. Another factor that may possibly influence caries susceptibility at the margins of abutment teeth, is the fact that the subgingival placement of the crown margin may possibly, under controlled oral health conditions, delay the exposure of cementum to the bacteria, until gingival recession has proceeded. The colonisation of root surfaces by acidogenic and aciduric bacteria creates an environment of low $\mathrm{pH}$, which, when it reaches the critical $\mathrm{pH}$ range of 5.0 to $5.5,{ }^{22}$ favours the demineralisation of the tooth's hard tissues. ${ }^{5}$

Textbooks $s^{23,24}$ and published research ${ }^{25}$ suggest the placement of the prosthetic restoration finish line supragingivally whenever possible, as utilisation of the pocket space increases the risk of periodontal inflammation. Subgingival restorative margins have been advocated for patients in high caries-risk groups. ${ }^{26}$ Other investigators have shown no influence of margin placement on caries incidence. ${ }^{25,27}$ The evidence regarding the relationship between prosthetic margin placement in relation to the gingival crevice and caries susceptibility seems inconclusive.

The purpose of this study was to systematically review the effect of prosthetic margin placement, in relation to the gingival crevice, on caries susceptibility of abutment teeth.

\section{METHODS}

\section{Methods of the review}

The protocol for this review was based on the PRISMA statement. ${ }^{28}$

\section{Search strategy}

The literature search was conducted by two reviewers (S. N. P. and A. P. P.) using electronic databases (Medline via PubMed, Embase, Google Scholar, Cochrane Central Register of Database of Systematic reviews [CDSR], Cochrane Central Register of Controlled Trials [CENTRAL] and Scopus) for clinical studies on humans reporting on prosthetic margins' caries susceptibility and location in relation to the gingival crest. The search covered the time span between each database's inception and March/April 2012. The same search terms were applied in all databases and included

\section{Table 1 Search strategy for the identification of articles}

\begin{tabular}{|c|c|c|}
\hline Database & Search strategy & Hits \\
\hline $\begin{array}{l}\text { MEDLINE searched } \\
\text { via PubMed (1950 - } \\
\text { week 2, April 2012) } \\
\text { www.ncbi.nlm.nih.gov/ } \\
\text { sites/entrez/ }\end{array}$ & $\begin{array}{l}\text { (randomised controlled trial[pt] OR controlled clinical trial[pt] } \\
\text { OR randomised controlled trials[mh] OR random allocation[mh] } \\
\text { OR double-blind method[mh] OR single-blind method[mh] } \\
\text { OR clinical trial[pt] OR clinical trials[mh] OR ('clinical trial'[tw]) } \\
\text { OR comparative study OR evaluation studies OR follow-up studies[mh] } \\
\text { OR prospective studies[mh] OR prospecti**[tw]) } \\
\text { AND (crowns OR 'fixed partial dentures' OR 'prosthetic restorations') } \\
\text { AND ([caries susceptibility] OR [decay susceptibility] OR caries* } \\
\text { OR decay* OR cavity*) }\end{array}$ & 769 \\
\hline $\begin{array}{l}\text { EMBASE searched } \\
\text { via ScienceDirect } \\
\text { (1974 - April, 2012) } \\
\text { www.embase.com }\end{array}$ & $\begin{array}{l}\text { (crowns OR 'fixed partial dentures' OR 'prosthetic restorations') } \\
\text { AND ([caries susceptibility*] OR [decay susceptibility*] OR caries* } \\
\text { OR decay* OR cavity*) } \\
\text { Limited to humans }\end{array}$ & 82 \\
\hline $\begin{array}{l}\text { Cochrane Database of } \\
\text { Systematic Reviews } \\
\text { searched via The } \\
\text { Cochrane Library at } \\
\text { April } 13,2012 \text { www. } \\
\text { thecochranelibrary.com }\end{array}$ & $\begin{array}{l}\text { (crowns OR 'fixed partial dentures' OR 'prosthetic restorations') } \\
\text { AND ([caries susceptibility*] OR [decay susceptibility*] OR caries* } \\
\text { OR decay* OR cavity*) } \\
\text { in All Fields }\end{array}$ & 38 \\
\hline $\begin{array}{l}\text { Cochrane Central } \\
\text { Register of Controlled } \\
\text { Trials searched via } \\
\text { The Cochrane Library } \\
\text { at April } 13,2012\end{array}$ & $\begin{array}{l}\text { (crowns OR 'fixed partial dentures' OR 'prosthetic restorations') } \\
\text { AND ((caries susceptibility*) OR (decay susceptibility*) OR caries* } \\
\text { OR decay* OR cavity*) } \\
\text { in All Fields }\end{array}$ & 149 \\
\hline $\begin{array}{l}\text { Google Scholar Beta } \\
\text { searched at April 13, } \\
2012 \text { www.scholar. } \\
\text { google.com }\end{array}$ & $\begin{array}{l}\text { (crowns OR 'fixed partial dentures' OR 'prosthetic restorations') } \\
\text { ([caries susceptibility*] OR [decay susceptibility*] OR caries* OR decay* } \\
\text { OR cavity*) Limited to medicine, pharmacology and veterinary science }\end{array}$ & 2,111 \\
\hline $\begin{array}{l}\text { Scopus searched at } \\
\text { April } 13,2012 \\
\text { www.scopus.com }\end{array}$ & $\begin{array}{l}\text { TITLE-ABS-KEY(crown* OR 'fixed partial denture*' OR 'prosthetic resto- } \\
\text { ration*') AND ('caries susceptibility' OR 'decay susceptibility' OR caries } \\
\text { OR decay* OR cavity) AND (LIMIT-TO(SUBJAREA, 'DENT') OR LIMIT- } \\
\text { TO(SUBJAREA, "MULT") }\end{array}$ & 2,392 \\
\hline \multicolumn{2}{|l|}{ SUM } & 5,541 \\
\hline
\end{tabular}

\section{Table 2 Kappa score for the agreement between authors}

\begin{tabular}{l|l|l} 
Criterion & Kappa & Interpretation \\
\hline Data selection procedure & & \\
\hline Mean follow-up period $>2$ years & 0.933 & Almost perfect agreement \\
\hline Number of patients stated & 0.879 & Almost perfect agreement \\
\hline Number of prostheses stated & 0.832 & Almost perfect agreement \\
\hline Margin location provided related to caries & 0.715 & Substantial agreement \\
\hline Data extraction procedure & 0.851 & Almost perfect agreement
\end{tabular}

the terms 'caries', 'decay' and 'cavity' combined with the following terms: 'crowns', 'fixed partial dentures', 'prosthetic restorations', 'subgingival', 'supragingival', 'margin', 'finish' and 'finish line' (Table 1). The search was augmented with the use of the 'related articles' option and cross-reference checking.

Additionally, hand searching was applied to the following journals for the time period of the search: Journal of Prosthetic Dentistry, International Journal of Prosthodontics, Journal of Dentistry and Caries Research.

\section{Selection of studies}

The selection process was conducted in two phases. During the first phase the titles and abstracts were screened by two of the authors (S. N. P. and A. P. P.) according to the following exclusion and inclusion criteria:

Exclusion criteria:

1. Laboratory studies

2. Case reports

3. Technical articles

4. Studies in a language other than English or without an English abstract. 


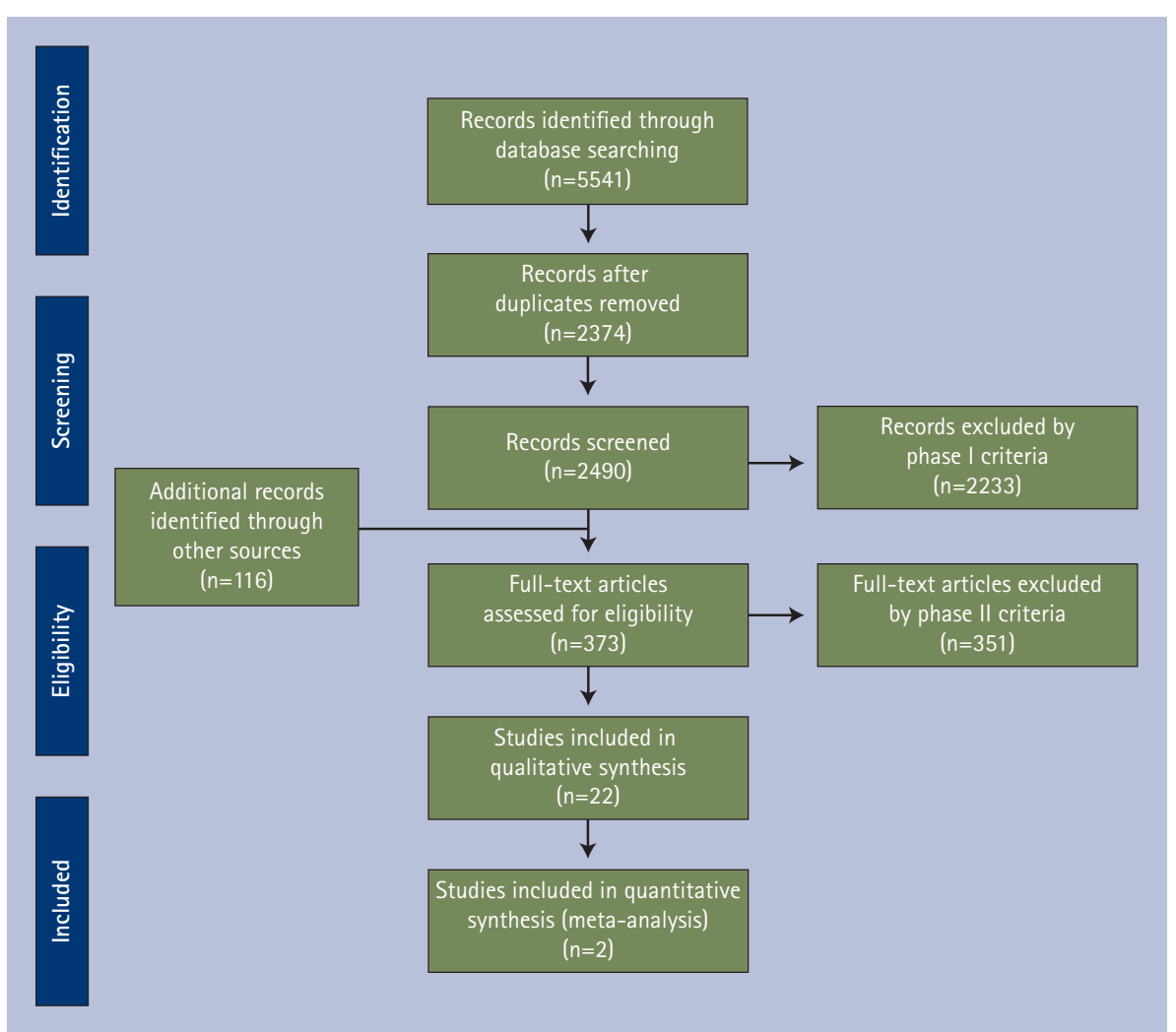

Fig. 1 Flow diagram of search results according to PRISMA statement

Inclusion criteria

1. Clinical studies (randomised controlled clinical trials, prospective or retrospective studies or case-control observational studies) reporting on caries susceptibility of teeth serving as abutments for prosthetic restorations

2. Study results provided by follow-up of patients.

Disagreements were resolved by discussion and in case of doubt the full-text of the article was obtained; if no agreement could be reached, the third author was consulted (H. P. P.). The full text of all articles that passed the first review phase was obtained. Additionally, manual search of the references of all full text articles selected, as well as hand searching of the selected dental journals was implemented at this point.

The second phase of the selection process was carried out by the two authors independently on the full-text of the studies obtained from the first phase using the following inclusion criteria:

1. Mean follow-up time of at least two years

2. Number of patients included in the study reported

3. Number of restorations and abutment teeth or abutment surfaces included in the study reported

4. Restorative margin location reported and associated to caries incidence.

The inter-reviewer agreement for the four inclusion criteria of the second phase of the selection process was determined using Cohen's unweighted kappa coefficient. In studies where only the minimum follow-up time was mentioned, that interval was used to measure the total exposure time of the restorations. In cases of multiple publications following the same cohort of patients, the study with the longest follow-up or the most complete record was taken into account. Restorative margin location was recorded as mentioned at the last clinical follow-up of each study.

\section{Study quality assessment}

The final included studies that passed the second review phase were classified according to the strength of evidence into four categories according to a previous published categorisation: ${ }^{29}$ A1 (controlled clinical trial with patient randomisation), A2 (controlled clinical trial with split-mouth randomisation), B (prospective controlled trial without randomisation), and C (clinical studies with designs other than category A and B-retrospective, case series, etc).

If no consensus was achieved on data selection and extraction, or methodological and descriptive assessment between the two independent observers (S. N. P. and A. P. P.), a third independent observer made the final decision (H. P. P.).

\section{Data synthesis}

Data of selected studies were tabulated according to demographical and clinical information. Caries incidence of prosthetic margins was studied at abutment or surface level, depending on study results. Trials were compared by grouping abutments teeth/abutment surfaces with subgingival margins as the experimental group and abutments teeth/abutment surfaces with equigingival or supragingival margins as the control group. Caries incidence was evaluated as a dichotomous variable. Direct analysis between experimental and control groups was performed whenever study design permitted and when definite caries incidence (excluding null ones) was provided for both groups. The risk ratio (RR) for caries incidence of prosthetic margins was calculated for the direct comparisons and pooled based on the random-effects model, ${ }^{30}$ with values below 1.0 favouring the experimental group (subgingival margins). Cumulative caries event rates/100 prosthesis years were reported for individual studies. The impact of statistical heterogeneity was assessed using the $\mathrm{I}^{2}$ statistic ${ }^{31}$ with $\mathrm{I}^{2}$ values over $50 \%$ indicating a substantial level of heterogeneity. All $\mathrm{P}$ values were two-sided with significance set at $p \leq 0.05$, except for $\mathrm{p}<0.10$ for the heterogeneity tests. Statistical analysis was performed using appropriate software (Review Manager 5.1, The Cochrane Collaboration, Oxford). The quality of evidence supporting the association between secondary caries and margin placement was assessed using the grading of recommendations, assessment, and evaluation (GRADE) system. ${ }^{32}$

\section{RESULTS}

Preliminary search of databases yielded 5,541 references (Table 1). One hundred and sixteen additional references were identified through reference lists and manual searching. Exclusion of duplicate references according to the initial screening left 


\begin{tabular}{|c|c|c|c|c|c|c|c|}
\hline Study & Setting & Design & $\begin{array}{l}\text { Planned sample } \\
\text { (M/F) }\end{array}$ & Dropouts (\%) & Actual sample & Mean age (range) & Measuring method \\
\hline \multicolumn{8}{|l|}{ Abutment studies } \\
\hline Burke et $a l^{33}$ & University & $C(R)$ & 30 & 17 & 25 & $37.3(24.0-63.0)$ & USPHS \\
\hline Burke et $a l^{34}$ & University & $C(P)$ & 16 & 19 & 16 & $37.5(22.0-51.0)$ & USPHS \\
\hline De Backer et al. ${ }^{35}$ & University & $C(R)$ & NR & NR & 456 & $41.0(18.0-82.0)$ & Custom \\
\hline De Backer et al. ${ }^{36}$ & University & $C(R)$ & NR & NR & 193 & $64.2(33.6-94.2)$ & Custom \\
\hline Guess and Stappert ${ }^{37}$ & University & $C(P)$ & $25(13 / 12)$ & 64 & 9 & $44.44(19-64)^{*}$ & USPHS \\
\hline Koch and García-Godoy ${ }^{38}$ & University & $C(R)$ & 12 & 0 & 12 & NR (6.0-8.0) & Custom \\
\hline Kokubo et al.39 & University & $C(P)$ & $57(6 / 51)$ & 19 & 46 & $46.4(20-70)^{*}$ & CDA \\
\hline Molin and Karlsson ${ }^{40}$ & University & $C(P)$ & $18(6 / 12)$ & 0 & 18 & $58.0(48.0-84.0)$ & CDA \\
\hline Näpänkangas et al.41 & University & $C(R)$ & 60 & 50 & 30 & $41.3(23.0-65.0)$ & Custom \\
\hline Schmitt et al..$^{42}$ & University & $C(P)$ & $30(17 / 13)$ & 10 & 27 & 52.2 (NR) & CDA \\
\hline Sorensen et al..$^{43}$ & University & $C(P)$ & 33 & 0 & 33 & NR (17.0-69.0) & Custom \\
\hline Sorrentino et al. ${ }^{44}$ & University/Private & $C(R)$ & $112(39 / 73)^{* *}$ & NR & NR & NR $(18-69)^{*}$ & CDA \\
\hline Toksavul and Toman ${ }^{45}$ & University & $C(P)$ & $21(5 / 16)$ & 0 & 21 & $38.28(18.0-60.0)$ & USPHS \\
\hline Vult von Steyern et al..$^{46}$ & University & $C(P)$ & 18 (9/9) & 0 & 18 & NR (37.0-76.0) & CDA \\
\hline \multicolumn{8}{|l|}{ Surface studies } \\
\hline Cehreli et al. ${ }^{47}$ & NR & A1 & $20(9 / 11)$ & 0 & 20 & 36.2 (NR) & CDA \\
\hline Ericson et al. ${ }^{27}$ & University & $C(P)$ & 39 & 23 & 30 & $56.4(27.0-80.0)$ & Custom \\
\hline Molin et $a .^{26}$ & PDHS/Private & $C(R)$ & 74 & 23 & 57 & $64.4(43.0-84.0)$ & Custom \\
\hline Nilson et al.48 & PDHS/Private & $C(R)$ & $24(10 / 14)$ & 8 & 22 & $47.8(30-67)$ & CDA \\
\hline Pippin et al..$^{49}$ & University & $C(R)$ & $30(13 / 17)$ & 0 & 30 & $36.0(18 .-77.0)$ & CDA \\
\hline Raigrodski et al.50 & University & $C(P)$ & $16(3 / 13)$ & 0 & 16 & 48 (36.0-60.0) & USPHS \\
\hline Tartaglia et al..51 & Private & $C(P)$ & $142(69 / 73)$ & 24 & 108 & $49.2(28-82)$ & FDI \\
\hline Valderhaug et $a l^{52}$ & University & B & $102(29 / 73)$ & 46 & 55 & $48.0(25.0-69.0)$ & Custom \\
\hline
\end{tabular}

2,490 references for evaluation. A total of 2,233 and 351 references were eliminated by the criteria of phase I and phase II respectively. Twenty-two studies were finally included in the qualitative synthesis. . $6,27,33-52^{2}$ Inter-reviewer agreement during the second review phase ranged from 'substantial agreement' to 'almost perfect agreement' (kappa: 0.715 - 0.933) (Table 2). The flowchart of the results and the review process according to the PRISMA statement is provided in Figure 1.

The 22 included studies corresponded to a total of 2,648 prosthetic restorations placed in 1,242 patients with mean followup time ranging between 2 to 11.4 years. All selected studies were published between 1990 and 2012. Most of the studies were classified as category $\mathrm{C}$ according to the strength of evidence. ${ }^{29}$ The majority of the selected studies were carried out in a university setting. The demographics and design of the included studies are described in detail in Tables 3 and 4.

The majority of the selected studies reported on the survival of fixed partial dentures (FPDs) and single crowns (SCs). Out of the 22 final studies only 5 reported that secondary caries had occurred. ${ }^{26,27,35,36,52}$ One study ${ }^{49}$ provided data for both porcelain-fused-to-metal crowns and porcelain laminate veneers, but only the latter were eligible to be included. Another study reported data on both tooth-supported and implant-supported crowns, but only the former are here reported. ${ }^{44}$ One study ${ }^{26}$ reported on conical crowns used under overdentures. Another, ${ }^{51}$ assessing single or multiple prosthetic crowns, reported margin location only for the buccal and lingual surfaces, and only those were included. The selected studies showed great variation regarding age of sample, examination methods, primary outcomes, statistical analysis and reporting of results. Only three studies ${ }^{26,27,52}$ made a direct comparison of caries incidence between control and experimental groups, all on surface level. The study ${ }^{26}$ on conical crowns under overdentures was judged to investigate a different microbiological environment compared to that of fixed prostheses and was excluded from the meta-analysis, finally leaving two eligible studies. ${ }^{27,52}$ 


\begin{tabular}{|c|c|c|c|c|c|c|c|c|}
\hline Study & Restoration & $\begin{array}{l}\text { Planned } \\
\text { no. of } \\
\text { restorations }\end{array}$ & $\begin{array}{l}\text { Drop- } \\
\text { outs (\%) }\end{array}$ & $\begin{array}{l}\text { Actual } \\
\text { no. of } \\
\text { restorations }\end{array}$ & $\begin{array}{l}\text { No. of } \\
\text { surfaces/teeth } \\
\text { (Ctr/Subg) }\end{array}$ & $\begin{array}{l}\text { Mean follow- } \\
\text { up (range) y }\end{array}$ & $\begin{array}{l}\text { Caries } \\
\text { incidence }\end{array}$ & $\begin{array}{l}\text { Estimated caries } \\
\text { rate per } 100 \text { years } \\
\text { (Ctr/Subg) }\end{array}$ \\
\hline \multicolumn{9}{|l|}{ Tooth level studies } \\
\hline Burke et $a l^{33}$ & SC & NR & NR & 60 & $60(49 / 11)$ & $2.4(2.0-5.0)$ & $0 / 0$ & $0 / 0$ \\
\hline Burke et $a l^{34}$ & SC & 59 & 19 & 48 & $48(48 / 0)$ & $3.9(3.0-4.5)$ & O/NA & O/NA \\
\hline De Backer et al. ${ }^{35}$ & SC & 1312 & 21 & 1037 & 1037 (1037/0) & $10.0(0.3-25.0)$ & 249/NA & $2.4 / \mathrm{NA}$ \\
\hline De Backer et al. ${ }^{36}$ & FPD & 397 & 19 & 322 & $704(704 / 0)$ & $11.4(0.5-26.3)$ & $84 / \mathrm{NA}$ & 1.05/NA \\
\hline Guess and Stappert ${ }^{37}$ & PLV & 66 & 65 & 23 & $23(23 / 0)$ & 5.0 & O/NA & O/NA \\
\hline Koch and Garcia-Godoy ${ }^{38}$ & SC & 41 & 0 & 41 & $41(39 / 2)$ & $3.0(2.0-5.0)$ & $0 / 0$ & $0 / 0$ \\
\hline Kokubo et al..$^{39}$ & SC & 101 & 26 & 75 & $75(0 / 75)$ & 5.0 & $\mathrm{NA} / \mathrm{O}$ & $\mathrm{NA} / \mathrm{O}$ \\
\hline Molin and Karlsson ${ }^{40}$ & FPD & 19 & 0 & 19 & $38(36 / 2)$ & 5.0 & $0 / 0$ & $0 / 0$ \\
\hline Näpänkangas et al..11 & SC/FPD & NR & NR & $24 F P D, 41 S C$ & $102(95 / 7)$ & 10.0 & $0 / 0$ & $0 / 0$ \\
\hline Schmitt et al.42 & FPD & 30 & 10 & 27 & $54(0 / 54)$ & 2.9 & $\mathrm{NA} / \mathrm{O}$ & $\mathrm{NA} / \mathrm{O}$ \\
\hline Sorensen et al. ${ }^{43}$ & SC & 75 & 0 & 75 & $75(0 / 75)$ & 3.0 & $\mathrm{NA} / 0$ & $\mathrm{NA} / \mathrm{O}$ \\
\hline Sorrentino et al. ${ }^{44}$ & SC & 128 & 2 & 126 & $126(0 / 126)$ & 6.0 & $\mathrm{NA} / \mathrm{O}$ & $\mathrm{NA} / \mathrm{O}$ \\
\hline Toksavul and Toman ${ }^{45}$ & SC & 79 & 0 & 79 & $79(23 / 56)$ & $4.8(1.0-5.0)$ & $0 / 0$ & $0 / 0$ \\
\hline Vult von Steyern et al. ${ }^{46}$ & FPD & 20 & 0 & 20 & $56(56 / 0)$ & 2.0 & $0 / 0$ & O/NA \\
\hline \multicolumn{9}{|l|}{ Surface level studies } \\
\hline Cehreli et al..47 & SC & 30 & 0 & 30 & $120(90 / 30)$ & 2.0 & $0 / 0$ & $0 / 0$ \\
\hline Ericson et al. ${ }^{27}$ & FPD & NR & NR & 33 & $376(216 / 160)$ & 3.0 & $5 / 6$ & $0.77 / 1.25$ \\
\hline Molin et al. ${ }^{26}$ & $\begin{array}{l}\text { Conical } \\
\text { crowns-retained } \\
\text { overdenture }\end{array}$ & NR & NR & 60 & $952(327 / 625)$ & $2.5(0.3-6.3)$ & NC & $\mathrm{NC}$ \\
\hline Nilson et al. ${ }^{48}$ & SC & 47 & 6 & 44 & 176 (83/93) & $2.2(2.2-2.5)$ & $0 / 0$ & $0 / 0$ \\
\hline Pippin et al. ${ }^{49}$ & PLV & 60 & 0 & 60 & $120(105 / 15)$ & $3.5(2.1-5.0)$ & $0 / 0$ & $0 / 0$ \\
\hline Raigrodski et al. ${ }^{50}$ & FPD & 20 & 0 & 20 & $160(120 / 40)$ & $2.6(1.5-3.0)$ & $0 / 0$ & $0 / 0$ \\
\hline Tartaglia et $a . .^{51}$ & SC/Multiple SC & 283 & 6 & 265 & $890(445 / 445)$ & 3.0 & 0/0 & $0 / 0$ \\
\hline Valderhaug et al..$^{52}$ & FPD & 108 & 45 & 59 & 719 (258/461) & 15.0 & $39 / 47$ & $1.01 / 0.68^{*}$ \\
\hline
\end{tabular}

The included studies were stratified according to whether location of margins on the abutment was reported at tooth level or at surface level. In most of the studies the location of the margins was placed at the gingival crest or above. Among the 14 studies measuring caries on

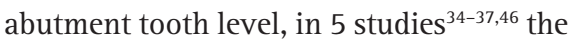
margins were placed solely equigingivally/ supragingivally, in 4 studies $^{39,42-44}$ solely subgingivally and in the last $5^{33,38,40,41,45}$ a combination of the above. Of the total of 2,516 abutment teeth included, 2,110 (83.9\%) had the margins placed at or above the gingival level whereas 406 (16.1\%) had subgingival margins. Estimated caries rate per 100 years for abutment teeth in individual studies ranged from 0 to 2.40 in the control group, while in the subgingival group no caries was observed.

In all of the seven studies ${ }^{27,47-52}$ measuring caries on abutment surface level the margins were placed both supragingivally/ equigingivally and subgingivally. Of the total 3,153 surfaces examined, 1,607 (51.0\%) had supragingival/equigingival margins, while 1,546 (49.0\%) had subgingival margins. Estimated caries rate per 100 years for surfaces in the control group ranged from 0 to 1.01 , while in the subgingival group from 0 to 1.25 (Table 4). Most of the studies used a standard index for clinical evaluation (CDA, ${ }^{53}$ USPHS-Ryge criteria, ${ }^{54}$ FDI WDF criteria ${ }^{55}$ ) whereas eight studies did not use a specific clinical index.

\section{Meta-analysis}

Two studies ${ }^{27,52}$ detected marginal secondary caries both supra- or equigingivally and subgingivally and could directly compare caries incidence on abutment surface level (Table 5). The first ${ }^{27}$ provided data after a mean follow-up of 3 years and the second ${ }^{51}$ after a mean follow-up of 5, 10 and 15 years. The results of the two studies ${ }^{27,52}$ were combined for the calculation of the 5-year RRs, whereas 


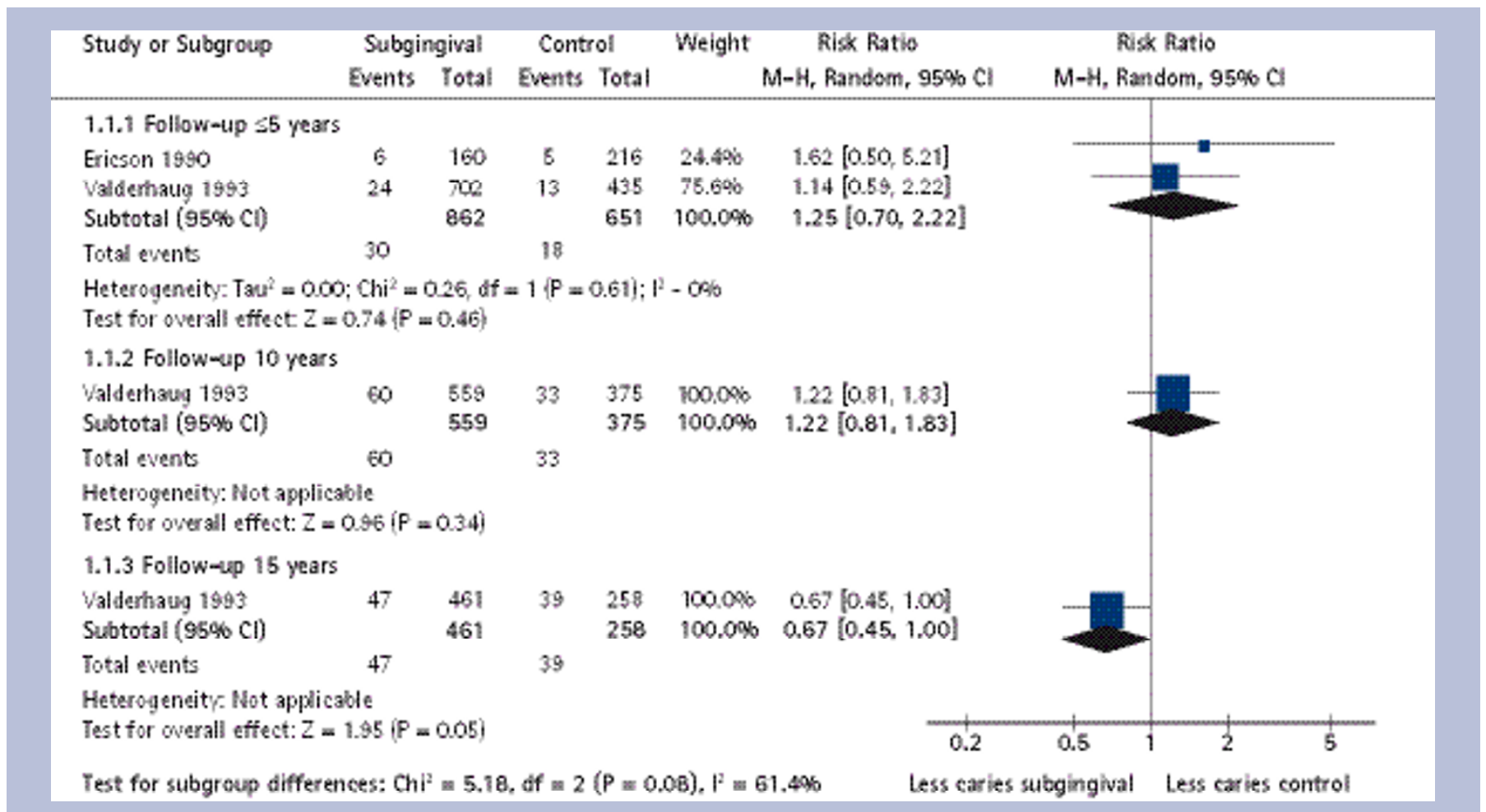

Fig. 2 Incidence of secondary caries between abutment surfaces with subgingival and equigingival/supragingival margins. Direct data with surface as the measurement unit (Risk ratio, Mantel-Haenszel, Random-effects model)

the 10 and 15 year RRs were based only on the study by Valderhaug et al. ${ }^{52}$ The pooled RR for secondary caries of subgingival margins at up to five years of follow-up (Fig. 2) using a random-effects model was 1.25 (95\% CI: 0.70 to 2.22 ) with $\mathrm{p}>0.05$ and no heterogeneity $\left(\mathrm{I}^{2}=0\right)$. The respective RR at ten years of follow-up was 1.22 (95\% CI: 0.81 to 1.83 ) with $\mathrm{p}>0.05$. However, at 15 years of follow-up, the RR was 0.67 (95\% CI: 0.45 to 1.00) with $\mathrm{p}=0.05$. Significant differentiation of the secondary caries incidence between the different follow-ups was found ( $p=0.08)$. Since only observational studies were included, all assessments started as 'low quality', which was further downgraded to 'very low quality', due to imprecision of the observed effect estimates (that is, both study effect estimates had wide 95\% CIs that crossed the line of null effect) (Table 5).

The possibility of publication bias could not be assessed due to the small number of studies.

\section{DISCUSSION}

To the authors' knowledge this is the first time that a systematic approach has been adopted to address the question of whether the prosthetic margin location relevant to

\section{Table 5 GRADE summary of findings table for caries rates of marginal surfaces}

\begin{tabular}{|c|c|c|c|c|c|c|}
\hline \multicolumn{7}{|c|}{$\begin{array}{l}\text { Patients: receiving fixed partial dentures for replacing missing te } \\
\text { Settings: university clinic } \\
\text { Intervention: prosthetic margin placed subgingivally } \\
\text { Comparison: prosthetic margin placed equi- or supragingivally }\end{array}$} \\
\hline \multirow{3}{*}{$\begin{array}{l}\text { Outcome } \\
\text { (follow-up) }\end{array}$} & \multicolumn{2}{|c|}{$\begin{array}{l}\text { Illustrative comparative } \\
\text { risks }(95 \% \mathrm{Cl})\end{array}$} & \multirow{3}{*}{$\begin{array}{l}\text { Relative } \\
\text { effect } \\
(95 \% \mathrm{Cl})\end{array}$} & \multirow{3}{*}{$\begin{array}{l}\text { No of } \\
\text { partici- } \\
\text { pants } \\
\text { (trials) }\end{array}$} & \multirow{3}{*}{$\begin{array}{l}\text { Quality of } \\
\text { evidence } \\
\text { (GRADE) }\end{array}$} & \multirow{3}{*}{ Comments } \\
\hline & \multirow{2}{*}{$\begin{array}{l}\text { Assumed } \\
\text { caries risk } \\
\text { Control } \\
\text { margins }\end{array}$} & \multirow{2}{*}{$\begin{array}{l}\text { Corresponding } \\
\text { caries risk } \\
\begin{array}{l}\text { Subgingival } \\
\text { margins }\end{array} \\
\end{array}$} & & & & \\
\hline & & & & & & \\
\hline $\begin{array}{l}\text { Marginal caries } \\
\text { incidence (follow- } \\
\text { up: } 3 \text { to } 5 \text { years) }\end{array}$ & $\begin{array}{l}2.8 \text { per } \\
100 \text { margin } \\
\text { surfaces }\end{array}$ & $\begin{array}{l}3.5 \text { per } \\
100 \text { margin } \\
\text { surfaces } \\
(1.9 \text { to } 6.1)\end{array}$ & $\begin{array}{l}\text { RR } 1.25 \\
(0.70 \text { to } \\
2.22)\end{array}$ & 85 (2) & $\begin{array}{l}\oplus \circ 00 \\
\text { very low' }\end{array}$ & $\begin{array}{l}p=0.460 \\
1^{2}=0 \%\end{array}$ \\
\hline $\begin{array}{l}\text { Marginal caries } \\
\text { incidence (follow- } \\
\text { up: } 10 \text { years) }\end{array}$ & $\begin{array}{l}8.8 \text { per } \\
100 \text { margin } \\
\text { surfaces }\end{array}$ & $\begin{array}{l}10.7 \text { per } \\
100 \text { margin } \\
\text { surfaces } \\
\text { (7.1 to } 16.1)\end{array}$ & $\begin{array}{l}\text { RR } 1.22 \\
(0.81 \text { to } \\
1.83)\end{array}$ & $55(1)$ & $\begin{array}{l}\oplus 000 \\
\text { very low }\end{array}$ & $p=0.340$ \\
\hline $\begin{array}{l}\text { Marginal caries } \\
\text { incidence (follow- } \\
\text { up: } 15 \text { years) }\end{array}$ & $\begin{array}{l}15.1 \text { per } \\
100 \text { margin } \\
\text { surfaces }\end{array}$ & $\begin{array}{l}10.1 \text { per } \\
100 \text { margin } \\
\text { surfaces } \\
\text { (6.8 to } 15.1)\end{array}$ & $\begin{array}{l}\text { RR } 0.67 \\
(0.45 \text { to } \\
1.00)\end{array}$ & $55(1)$ & $\begin{array}{l}\oplus 000 \\
\text { very low }\end{array}$ & $p=0.050$ \\
\hline
\end{tabular}

1-Downgraded by 1 for imprecision: both study effect estimates had wide $95 \%$ Cls that cross the line of null effect and no criteria for quality upgrade were met.

Test for subgroup differences between the three timepoints: $p=0.080 ; \mathrm{l}^{2}=61 \%$.

$\mathrm{Cl}$, confidence interval; $\mathrm{RR}$, relative risk.

the free gingival margin can influence the incidence of secondary caries. The theory behind this question was founded on the differences that exist between the micro-environment within the gingival crevice compared to the rest of the oral environment. ${ }^{5}$ This study included data from 22 studies following 2,648 prosthetic restorations. The main finding of this systematic review was that placement of the crown margin subgingivally was not associated with lower secondary caries rate in the short to mid-term. Some indications existed, however, that 
it may have influenced the long-term (>ten years) incidence of marginal caries, although this finding was based on one study, ${ }^{52}$ and the quality of evidence was low. Nevertheless, the clinical significance of the results should be appraised. In the groups of patients followed in the included studies, secondary caries rates were very low. These rates are in agreement with caries rates reported in a review of complications of tooth-supported fixed prostheses. ${ }^{14}$ The minimum follow-up time was set at two years as this period is considered as the minimum time required for the progression of caries on dentine surfaces. ${ }^{56,57}$ In reality, very little is known about the mechanisms and progression of secondary caries in fixed prosthodontics. The low overall secondary caries incidence may be the result of properly designed and executed treatment planning protocols, as well as closer follow-up and maintenance of these cohorts of patients since most were treated in university settings. Therefore, for such groups of patients, under proper oral hygiene and maintenance protocols, the location of prosthetic margin placement may not be critical.

Certain limitations concerning the meta-analytical part must be acknowledged. This study included only published studies that had been peer-reviewed and could possibly provide a false estimate. ${ }^{57}$ Few studies were detected with valid direct comparisons, diminishing the precision and power of the estimate. Most studies were of moderate quality; only one RCT was identified. Incomplete reporting of the studies precluded the analysis per patient mouth, as would be more appropriate since individual abutment teeth or surfaces are not absolutely independent variables. The possibility that the results were biased by publication bias could not be ruled out. The included studies presented with clinical variability and different clinical indices, some of them non-standardised, were used for quality evaluation of prostheses. It is important for future studies to utilise standardised and validated criteria for quality evaluation of prostheses.

Another issue to consider was the classification of margin placement, which might partly explain the long-term differences observed between control and experimental groups. Margin placement was classified according to study reporting at the last recall. Taking into account the fact that, in many cases, a continuous gingival recession occurs around teeth ${ }^{25,58}$ the results of this study may represent an underestimation of secondary caries occurring on subgingival prosthetic margins. Bearing that in mind, the comparison across different time-points of patient recall made in Figure 2 is of great interest. After a mean follow-up of 15 years a fair amount of gingival recession can be expected to have happened, enabling different cementum exposures to be expressed in the caries incidence. The possibility exists that the lower long-term marginal caries rate for subgingival margins reflects the fact that cementum exposure is delayed until gingival recession has occurred beyond the crown margin to expose it. Another fact to consider is that carious lesions under the gingival margin (root caries) are more difficult to identify and to treat compared to coronal caries and so it might have been under-reported. Comparisons with other studies are limited, as the literature has mainly focused on the effect of prosthetic margin placement on various periodontal indices. Differences in gingival scores have been previously reported for crowns with subgingival finish lines compared to both crowns with equi-/supragingival margins and teeth without crowns. ${ }^{59}$ This detrimental effect begins to appear one to three years after placement and improves concomitantly, possibly as some subgingival margins become equi- or supragingival. ${ }^{60}$ A greater chance of gingival recession was recorded for subgingival restorations regardless of depth of sulcus penetration. ${ }^{61}$ Thus, the role of subgingival placement of the prosthetic margins may diminish in the long-term.

Bearing in mind that G. V. Black's principles of 'extension for prevention' no longer apply, ${ }^{62}$ the choice of placing prosthetic margins subgingivally needs to be carefully justified, weighing accompanying risks like more dentine removal; weakened teeth; higher operator skill requirements; root sensitivity; higher chance for pulpal exposure, therefore compromising tooth vitality; more complex impression making; and difficulty of accurate assessment of margin integrity and tooth vitality.

Further well-designed randomised splitmouth clinical studies need to be conducted to analyse the effect of prosthetic margin placement on the risk of secondary caries.

\section{CONCLUSIONS}

This systematic review and meta-analysis failed to detect a significantly different secondary caries rate of subgingivally located prosthetic margins in the short to mid-term (sten years). Due to the small number and the limitations of the included studies the results do not provide conclusive evidence as to the effect of prosthetic margin placement on the incidence of secondary caries.

1. Selwitz R H, Ismail A I, Pitts N B. Dental caries. Lancet 2007; 369: 51-59.

2. Loesche W J. Role of Streptococcus mutans in human dental decay. Microbiol Rev 1986; 50: 353-380.

3. van Houte $J$. Role of microorganisms in caries aetiology. J Dent Res 1994; 73: 672-681.

4. Burt B A, Loesche W J, Eklund S A. Stability of selected plaque species and their relationship to caries in a child population over 2 years. Caries Res 1985; 19: 193-200.

5. Marcotte H, Lavoie M C. Oral microbial ecology and the role of salivary immunoglobulin A. Microbiol Mol Biol Rev 1998; 62: 71-109.

6. Nyvad B. Microbial colonization of human tooth surfaces. Acta Pathol Microbiol Immunol Scand 1993; 101: 7-45.

7. Beltran-Aguilar E D, Beltran-Neira R J. Oral diseases and conditions throughout the lifespan. I. Diseases and conditions directly associated with tooth loss. Gen Dent 2004; 52: 21-27.

8. Featherstone J, Domejean-Orliaguet $S$, Jenson L, Wolff M, Young D A. Caries risk assessment in practice for age 6 through adult. J Calid Dent Assoc 2007; 35: 703-713

9. Petersen P E, Yamamoto T. Improving the oral health of older people: the approach of the WHO Global Oral Health Programme. Community Dent Oral Epidemiol 2005; 33: 81-92.

10. Reich E, Lussi A, Newbrun E. Caries-risk assessment Int Dent J 1999; 49: 15-26.

11. Richards W, Ameen J, Coll A M, Higgs G. Reasons for tooth extraction in four general dental practices in South Wales. Br Dent J 2005; 198: 275-278.

12. Slootweg P J. Dental pathology: a practical introduction. Berlin, Heidelberg: Springer-Verlag, 2007.

13. Tagliaferro E P, Ambrosano G M, Meneghim Mde C, Pereira A C. Risk indicators and risk predictors of dental caries in schoolchildren. J App/Oral Sci 2008; 16: 408-413.

14. Goodacre C J, Bernal G, Rungcharassaeng K, Kan $J$ Y. Clinical complications in fixed prosthodontics. J Prosthet Dent 2003; 90: 31-41.

15. Köhler B, Hager B. Influence of salivary levels of mutans streptococci on colonization of crown margins: a longitudinal study. J Prosthet Dent 1993; 69: 524-528.

16. Tanaka J, Mukai N, Tanaka M, Tanaka M. Relationship between xariogenic bacteria and $\mathrm{pH}$ of dental plaque at margin of fixed prostheses. Int J Dent 2012; Article ID 452108. doi: 10.1155/2012/452108

17. Meyer D H, Fives-Taylor P M. Oral pathogens: from dental plaque to cardiac disease. Curr Opin Microbiol 1998; 1: 88-95.

18. van Palenstein Helderman W H. Longitudinal microbial changes in developing human supra-gingival and subgingival dental plaque. Arch Oral Biol 1981; 26: 7-12.

19. Bowden G H W, Ellwood D C, Hamilton I R. Microbial ecology of the oral cavity. Adv Microb Ecol $1979 ; 3:$ 135-217.

20. Hamilton I R, McKee A S, Bowden G H. Growth and metabolic properties of Bacteroides intermedius 
in anaerobic continuous culture. Oral Microbiol Immunol 1989; 4: 89-97.

21. McDermid A S, McKee A S, Marsh P D. Effect of environmental $\mathrm{pH}$ on enzyme activity and growth of Bacteroides gingivalis W50. Infect Immun 1988; 56: 1096-1100.

22. Loesche W J. Role of Streptococcus mutans in human dental decay. Microbiol Rev 1986; 50: 353-380.

23. Dimitrescu A L, Okada M, Inagaki K. Etiology and pathogenesis of periodontal disease. Heidelberg: Springer-Verlag, 2010.

24. Rosenstiel S F, Land M F, Fujimoto J. Contemporary fixed prosthodontics. 4th edn. St. Louis (MO): Mosby, 2006.

25. Valderhaug J. Periodontal conditions and carious lesions following the insertion of fixed prostheses: a 10-year follow-up study. Int Dent J 1980; 30: 296-304.

26. Molin M, Bergman B, Ericson A. A clinical evaluation of conical crown retained dentures. J Prosthet Dent 1993; 70: 251-256.

27. Ericson $G$, Nilson $H$, Bergman B. Cross-sectional study of patients fitted with fixed partial dentures with special reference to the caries situation. Scand J Dent Res 1990; 98: 8-16.

28. Liberati A, Altman D G, Tetzlaff J et al. The PRISMA statement for reporting systematic reviews and meta-analyses of studies that evaluate health care interventions: explanation and elaboration. Ann Intern Med 2009: 151: 65-94.

29. Jökstad A, Brägger U, Brunski J B et al. Quality of dental implants. Int Dent J 2003; 53: 409-443.

30. DerSimonian R, Laird N. Meta-analysis in clinical trials. Control Clin Trials 1986; 7: 177-188.

31. Higgins J P, Thompson S G, Deeks J J, Altman D G. Measuring inconsistency in meta-analyses. $B M J$ 2003; 327: 557-560.

32. Guyatt $G H, O x m a n A$ D, Schünemann H J, Tugwell $P$, Knottnerus A. GRADE guidelines: a new series of articles in the Journal of Clinical Epidemiology. J Clin Epidemiol 2011; 64: 380-382.

33. Burke F J, Qualtrough A J, Wilson N H. A retrospective evaluation of a series of dentin-bonded ceramic crowns. Quintessence Int 1998; 29: 103-106.

34. Burke F J. Four year performance of dentinebonded all-ceramic crowns. Br Dent J 2007; 202: 269-273.

35. De Backer H, Van Maele G, De Moor N, Van den Berghe L. Survival of complete crowns and periodontal health: 18-year retrospective study. Int J Prosthodont 2007; 2: 151-158.
36. De Backer H, Van Maele G, De Moor N, Van den Berghe L. Long-term results of short-span versus long-span fixed dental prostheses: an up to 20-year retrospective study. Int J Prosthodont 2008; 21: 75-85.

37. Guess P C, Stappert C F. Midterm results of a 5-year prospective clinical investigation of extended ceramic veneers. Dent Mater 2008; 24: 804-813.

38. Koch M J, Garcia-Godoy F. The clinical performance of laboratory-fabricated crowns placed on first permanent molars with developmental defects. $J$ Am Dent Assoc 2000; 131: 1285-1290.

39. Kokubo Y, Sakurai S, Tsumita M, Ogawa T, Fukushima S. Clinical evaluation of Procera AllCeram crowns in Japanese patients: results after 5 years. J Oral Rehabil 2009; 36: 786-791.

40. Molin M K, Karlsson S L. Five-year clinical prospective evaluation of zirconia-based Denzir 3-unit FPDs. Int J Prosthodont 2008; 21: 223-227.

41. Näpänkangas R, Salonen M A, Raustia A M. A 10-year follow-up study of fixed metal ceramic prosthodontics. J Oral Rehabil 1997; 24: 713-717.

42. Schmitt J, Holst S, Wichmann M, Reich S, Gollner M, Hamel J. Zirconia posterior fixed partial dentures: a prospective clinical 3-year follow-up. Int J Prosthodont 2009; 22: 597-603

43. Sorensen J A, Choi C, Fanuscu M I, Mito W T. IPS Empress crown system: three-year clinical trial results. J Calif Dent Assoc 1998; 26: 130-136.

44. Sorrentino R, Galasso L, Tetè S, De Simone G, Zarone F. Clinical evaluation of 209 all-ceramic single crowns cemented on natural and implantsupported abutments with different luting agents: a 6-year retrospective study. Clin Implant Dent Relat Res 2012: 14: 184-197.

45. Toksavul S, Toman M. A short-term clinical evaluation of IPS Empress 2 crowns. Int J Prosthodont 2007: 20: 168-172.

46. Vult von Steyern P, Carlson P, Nilner K. All-ceramic fixed partial dentures designed according to the DC-Zirkon technique. A 2-year clinical study. J Oral Rehabil 2005; 32: 180-187.

47. Cehreli M C, Kokat A M, Akca K. CAD/CAM Zirconia vs. slip-cast glass-infiltrated Alumina/Zirconia all-ceramic crowns: 2-year results of a randomized controlled clinical trial. J App/ Oral Sci 2009; 17: 49-55.

48. Nilson $H$, Bergman $B$, Bessing $C$, Lundgvist $P$, Andersson M. Titanium copings veneered with Procera ceramics: a longitudinal clinical study. Int $J$ Prosthodont 1994; 7: 115-119.

49. Pippin D J, Mixson J M, Soldan-Els A P. Clinical evaluation of restored maxillary incisors: veneers vs. PFM crowns. J Am Dent Assoc 1995; 126 : 1523-1529.

50. Raigrodski A J, Chiche G J, Potiket $N$ et al. The efficacy of posterior three-unit zirconium-oxide-based ceramic fixed partial dental prostheses: a prospective clinical pilot study. J Prosthet Dent 2006; 96: 237-244.

51. Tartaglia G M, Sidoti E, Sforza C. A 3-year follow-up study of all-ceramic single and multiple crowns performed in a private practice: a prospective case series. Clinics (Sao Paulo) 2011; 66: 2063-2070.

52. Valderhaug J, Ellingsen J E, Jokstad A. Oral hygiene, periodontal conditions and carious lesions in patients treated with dental bridges. A 15-year clinical and radiographic follow-up study. J Clin Periodontol 1993; 20: 482-489.

53. California Dental Association. Quality evaluation for dental care: guidelines for assessment of clinical quality and professional performance. Los Angeles: California Dental Association, 1977.

54. Cvar J F, Ryge G. Reprint of criteria for the clinical evaluation of dental restorative materials. 1971. Clin Oral Investig 2005; 9: 215-232.

55. Hickel R, Peschke A, Tyas M et al. FDI World Dental Federation: clinical criteria for the evaluation of direct and indirect restorations-update and clinical examples. Clin Oral Investig 2010; 14: 349-366.

56. Robertson $\mathrm{T} M$, Heymann $\mathrm{H}$ O, Swift E J. Sturdevant's art and science of operative dentistry. 5th edn. St. Louis (M0): Mosby, 2002.

57. Pine $\mathrm{C}$, ten Bosch J J. Dynamics of and diagnostic methods for detecting small carious lesions. Caries Res 1996; 30: 381-388.

57. Borenstein $M$, Hedges L V, Higgins J P T, Rotherstein H R. Introduction to meta-analysis. Chichester: John Wiley and Sons Ltd, 2009.

58. Volchansky A, Cleaton-Jones P. Clinical crown height (length)-a review of published measurements. J Clin Periodonto/ 2001; 28: 1085-1090.

59. Gemalmaz D, Ergin S. Clinical evaluation of all-ceramic crowns. J Prosthet Dent 2002; 87: 189-196.

60. Schätzle $M$, Land N P, Anerud A, Boysen $H$, Bürgin W, Löe $H$. The influence of margins of restorations of the periodontal tissues over 26 years. J Clin Periodontol 2001; 28: 57-64.

61. Orkin D A, Reddy J, Bradshaw D. The relationship of the position of crown margins to gingival health. $J$ Prosthet Dent 1987; 57: 421-424.

62. Tyas M J, Anusavice K J, Frencken J E, Mount G J. Minimal intervention dentistry-a review. FDI Commission Project 1-97. Int Dent J 2000; 50: $1-12$. 